\title{
Cerebellar Syringocephaly Following Surgery for Chiari Malformation
}

Ismaël Mahazou, MD, Mohamed Choukri, MD, Fabrice Parker, MD, and Steven Knafo, MD, PhD

Neurology ${ }^{\circledR}$ 2021;97:38-39. doi:10.1212/WNL.0000000000012128

Figure Progression of Syringomyelia Toward Cerebellar Syringocephaly Following Posterior Fossa Decompression for Chiari Malformation
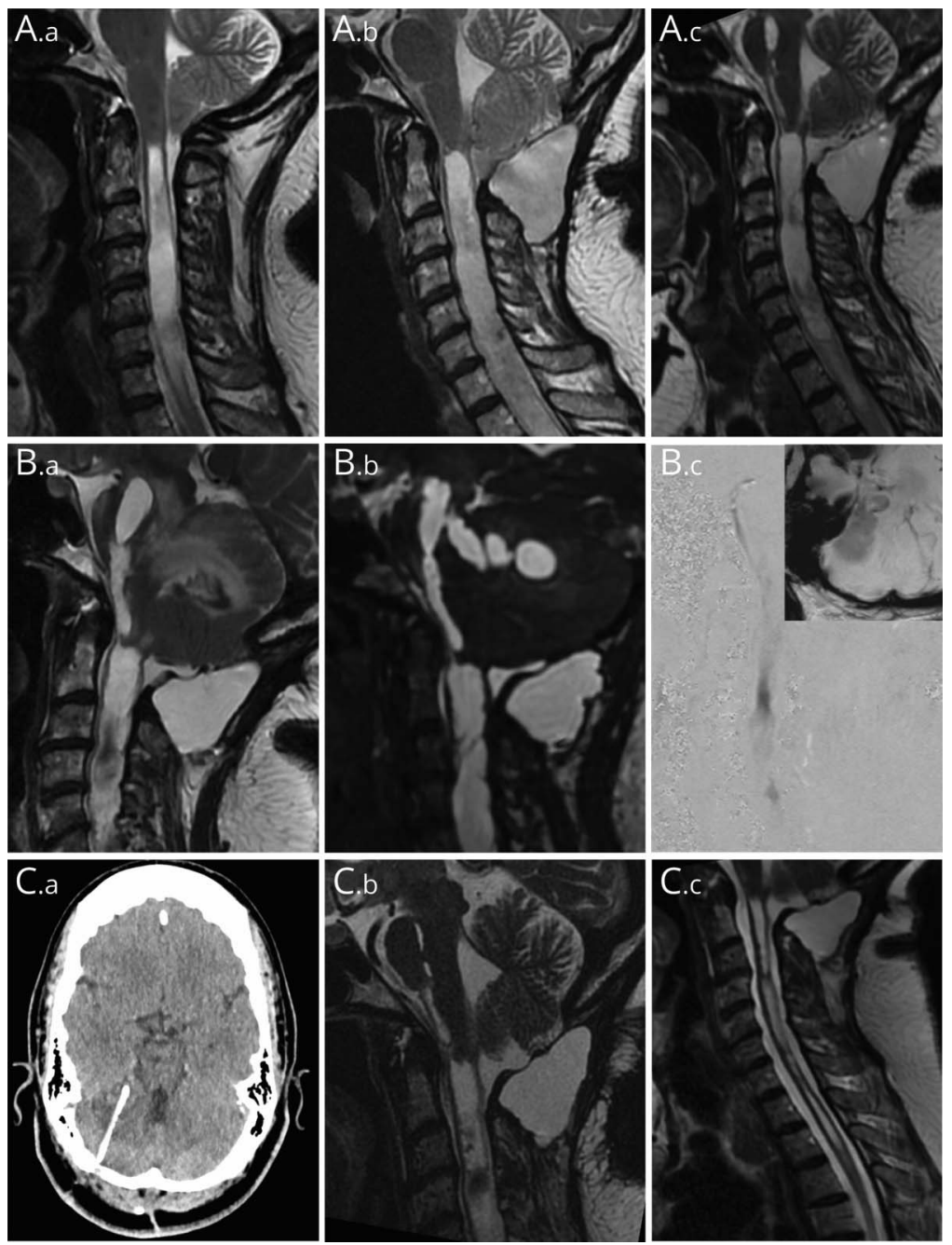

(A) Posterior decompression failure. (A.a) Chiari malformation with syringomyelia. (A.b) Foraminal arachnoiditis. (A.c) Progression toward syringobulbia. (B) Cerebellar syringocephaly. (B.a) Extension to the cerebellum. (B.b) communication and (B.C) CSF flow between cavities. (C) Resolution by cysto-peritoneal shunting. (C.a) Immediate postoperative CT scan. (C.b) 3-month and (C.c) 6-month postoperative MRI.

Extension of syringomyelia to the cerebral hemispheres, termed syringocephaly, is rare. ${ }^{1,2}$ We report the case of a 50-year-old woman who had undergone repeated posterior fossa decompression for Chiari malformation type I with syringomyelia, resulting in foraminal arachnoiditis. Two years later, she presented with cerebellar ataxia revealing a holocord progression of the syringomyelia, extending

\author{
Correspondence \\ Dr. Knafo \\ steven.knafo@aphp.fr
}


to the cerebellar hemispheres (figure, A). Millimetric T2-weighed and CSF flow sequences confirmed communication between cavities (figure, B). A cysto-peritoneal shunt was performed. Follow-up at 1 year demonstrated a marked improvement of cerebellar signs and complete radiologic regression of the cerebellar syringocephaly (figure, $\mathrm{C}$ ).

\section{Study Funding}

The authors report no targeted funding.

\section{Disclosure}

The authors report no disclosures relevant to the manuscript. Go to Neurology.org/N for full disclosures.

\section{Appendix Authors}

\begin{tabular}{lll}
\hline Author & Location & Contribution \\
\hline Ismaël & University & Drafting/revision of the manuscript for \\
Mahazou, MD & Paris-Saclay & content, including medical writing for content
\end{tabular}

\begin{tabular}{lll} 
Appendix & (continued) & \\
\hline Author & Location & Contribution \\
\hline $\begin{array}{l}\text { Mohamed } \\
\text { Choukri, MD }\end{array}$ & $\begin{array}{l}\text { University } \\
\text { Paris-Saclay }\end{array}$ & Major role in the acquisition of data \\
\hline $\begin{array}{l}\text { Fabrice } \\
\text { Parker, MD }\end{array}$ & $\begin{array}{l}\text { University } \\
\text { Paris-Saclay }\end{array}$ & Major role in the acquisition of data \\
\hline $\begin{array}{l}\text { Steven } \\
\text { Knafo, MD, } \\
\text { PhD }\end{array}$ & $\begin{array}{l}\text { University } \\
\text { Paris-Saclay }\end{array}$ & $\begin{array}{l}\text { Drafting/revision of the manuscript for } \\
\text { content, including medical writing for } \\
\text { content, major role in the acquisition of } \\
\text { data, study concept or design, analysis or } \\
\text { interpretation of data }\end{array}$ \\
\hline
\end{tabular}

\section{References}

1. Lee JH, Chung C-K, Kim HJ. Cerebral dissection from syringomyelia demonstrated using cine magnetic resonance imaging: case report. J Neurosurg. 2001;94(2): 318-321.

2. Aryan HE, Yanni DS, Nakaji P, Jandial R, Marshall LF, Taylor WR. Syringocephaly. J Clin Neurosci. 2004;11(4):421-423.

\section{COVID-19 and Neurologic Disease: Call for Papers!}

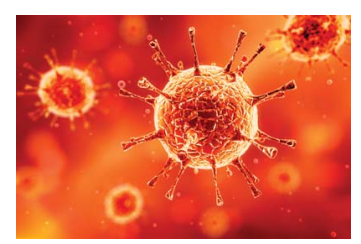

The editors of Neurology are interested in papers that address the neurological aspects of COVID-19 infection and challenges to the management of patients with chronic neurological conditions who have, or are at risk for, the infection. Relevant papers that pass initial internal review will undergo expedited peer review and online publication. We will consider papers posted in preprint servers.

Submit observational studies and clinical trials as Articles and case series and case reports under the Clinical/Scientific Notes category to https://submit.neurology.org/ today!

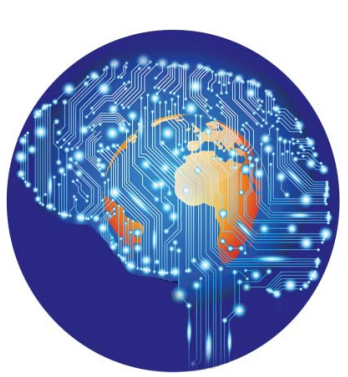

\section{Practice Current: An interactive exchange on controversial topics}

Share your own best practices.

Read commentary with expert opinion.

Explore results on an interactive world map.

NPub.org/NCP/practicecurrent

Neurology ${ }^{\circledR}$ Clinical Practice 


\section{Neurology}

Cerebellar Syringocephaly Following Surgery for Chiari Malformation

Ismaël Mahazou, Mohamed Choukri, Fabrice Parker, et al.

Neurology 2021;97;38-39 Published Online before print April 30, 2021

DOI 10.1212/WNL.0000000000012128

This information is current as of April 30, 2021

\begin{tabular}{|c|c|}
\hline $\begin{array}{l}\text { Updated Information \& } \\
\text { Services }\end{array}$ & $\begin{array}{l}\text { including high resolution figures, can be found at: } \\
\text { http://n.neurology.org/content/97/1/38.full }\end{array}$ \\
\hline References & $\begin{array}{l}\text { This article cites } 2 \text { articles, } 0 \text { of which you can access for free at: } \\
\text { http://n.neurology.org/content/97/1/38. full\#ref-list-1 }\end{array}$ \\
\hline Subspecialty Collections & $\begin{array}{l}\text { This article, along with others on similar topics, appears in the } \\
\text { following collection(s): } \\
\text { All Spinal Cord } \\
\text { http://n.neurology.org/cgi/collection/all_spinal_cord } \\
\text { Cerebrospinal Fluid } \\
\text { http://n.neurology.org/cgi/collection/cerebrospinal_fluid } \\
\text { MRI } \\
\text { http://n.neurology.org/cgi/collection/mri }\end{array}$ \\
\hline Permissions \& Licensing & $\begin{array}{l}\text { Information about reproducing this article in parts (figures,tables) or in } \\
\text { its entirety can be found online at: } \\
\text { http://www.neurology.org/about/about_the_journal\#permissions }\end{array}$ \\
\hline Reprints & $\begin{array}{l}\text { Information about ordering reprints can be found online: } \\
\text { http://n.neurology.org/subscribers/advertise }\end{array}$ \\
\hline
\end{tabular}

Neurology ${ }^{\circledR}$ is the official journal of the American Academy of Neurology. Published continuously since 1951, it is now a weekly with 48 issues per year. Copyright () 2021 American Academy of Neurology. All rights reserved. Print ISSN: 0028-3878. Online ISSN: 1526-632X.

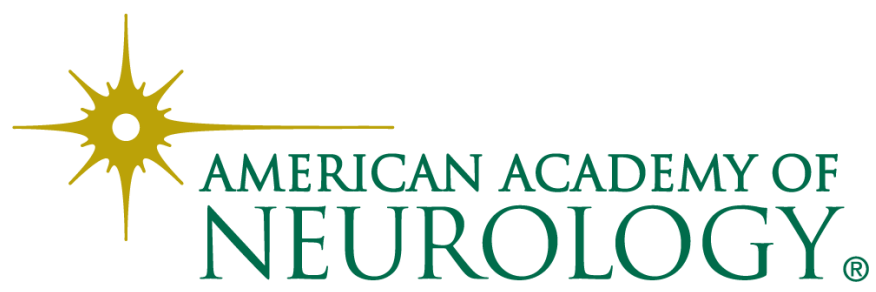

